\title{
ECLETICA
}

www.scielo.br/eq

Volume 31, número 4, 2006

\section{Determination of carbon monoxide using a coated quartz crystal sensor}

\author{
O. M. Guimarães ${ }^{1}$, M. E. D. Zaniquelli', J. R.M. Castro², V. R. Balbo ${ }^{2}$ and J. F. Andrade \\ ${ }^{1}$ Departamento de Química da UFPR/PR - 81531-990 - Curitiba - PR - Brazil \\ ${ }^{2}$ Departamento de Química FFCLRP/USP - 14040-901 - Ribeirão Preto - SP - Brazil.
}

\begin{abstract}
Carbon monoxide was detected and determined by a piezoelectric quartz crystal sensor coated with nickel(II)-phthalocyanine $50 \%$ (v/v) solution in glycerine. Studies on the effect of temperature, flow rate, and some possible interferents were carried out. Calibration curves, sensor stability (lifetime) and the precision of measurements were also verified. The resulting selectivity is probably due to the coordinative binding between the electronically unsatured metal complexes and the analyte. The analytical curve is linear in the concentration range 0.10 to $1.0 \%(\mathrm{v} / \mathrm{v})$.
\end{abstract}

Keywords: carbon monoxide; piezoelectric sensor; phthalocyanine nickel(II); quartz crystal.

\section{Introduction}

The principle of detection by piezoelectric crystal is based on the fact that the vibration frequency of an oscillating sensor decreases in the presence of an amount of material added to its surface. As shown by Sauerbrey [1], the vibrating frequency of a quartz crystal, to a first approximation, changes proportionally to the mass deposited onto or removed from one or both their faces. Because the TSMR (thickness shear mode resonator) fundamental frequency is rather low (10 $\mathrm{MHz}$ ), it is assumed that viscosity effects contribute to the frequency changes due to gas sorption to a negligible extent only [2]. Gaseous pollutants can be selectively sorbed by the detector if an ideal coating is deposited on the metallic electrodes. The observed frequency change is a measure of the amount of sorbed gas. The type of interaction taking place between the analyte molecules and the active coating determines the sorption and desorption characteristics. Lowenergy, perfectly reversible interactions such as physisorption generally lack a high degree of selectivity. On the other hand, the formation of chemical bonds or the chemisorption process tend to be less reversible. One approach to overcoming these problems includes the application of sensor arrays to compensate the low selectivity $[3,4]$. Another solution to this problem includes searching for "intermediate interactions", i.e., interactions that are weaker than chemisorption $\left(\approx 300 \mathrm{~kJ} \mathrm{~mol}^{-1}\right)$ but stronger than physisorption $(0$ $40 \mathrm{~kJ} \mathrm{~mol}^{-1}$ ), such as coordination [5]. A central metal atom surrounded by neutral or charged (often organic) ligands is responsible for these interactions, where one or more donor atoms on these ligands interact with the metal ion. So, selectivity can be influenced by the choice of both the metal ion and the ligand, from both an eletronic and steric point of view [5]. When gaseous molecules interact with metal complexes in this way, they themselves become coligands either by occupying free coordination sites or by displacing other ligands. Earlier work in the field of coordination chemistry on mass-sensitive 
transducers includes the monitoring of oxygen by using cobalt porphyrins and cobalt diamine complexes [6], the detection of $\mathrm{NH}_{3}$ and organophosphorous compounds [7,8], detection of water [9] and the application of an organoplatinum coating to detect butadiene [10] and styrene vapours [11,12] or to discriminate isomeric and structurally-related unsaturated organic compounds $[13,14]$. In most of cases, problems arise from a lack of reversibility [7-9]. Sometimes it is necessary to regenerate the sensors [11,12], with significant partial changes in sensitivity.

For many years 3-trifluoroacetyl (Tfa) and 3-heptafluorobutanoyl (Hfb) camphorates of transition metals such as manganese (II), cobalt (II) and nickel (II), and of lanthanides such as Europium (III) have been used as (chiral) additives to stationary phases in chromatography (chiralmetal) [15]. The selectivities are based on the interactions of these coordinatively and eletronically unsaturated metal complexes with analytes containing heteroatoms such as $\mathrm{O}$ and $\mathrm{N}$. These materials have been applied to the detection and determination of volatile organic compounds (VOC's) containing oxygen, nitrogen, but bearing no heteroatoms [16].

Phthalocyanines (Pcs) are organic compounds that are able to act as chemically sensitive films. The properties of phthalocyanines, particularly their ionization potentials, can be varied by metal-ion insertion and by the attachment of additional atoms or groups which enhance or diminish the ionization potential according to their position on the electronegativity scale. Variation of the substituents on the side chain and the ligand or $\mu$-bridge in their polymers leads to different detection properties for environmentally relevant gases. This allows the production of carefully designed and optimized thin films having different degrees of sensitivity, selectivity, and stability. In addition, these films have high chemical and thermal stability toward many environmental conditions. They can be easily produced as films through coating methods such as sublimation, spraying, and smearing [17]. The interactions between the Pc films and the gases may be classified in terms of irreversible chemical affinity, reversible chemical reaction (usually charge-transfer), or bulk sorption. These interactions result in detectable changes in the physical properties of the films, which include conductivity, mass, and optical properties [17].

In this study, which is part of a systematic investigation in our laboratory [18,19], we have proposed a phthalocyanine nickel(II) coating for the detection and determination of carbon monoxide in air, using a piezoelectric crystal sensor. Sensitivity, response time, reversibility, as well as stability, selectivity, and reproducibility of the detector were examined. Moreover, the effects of the working flow rate, temperature, and possible interferents on the responses have been discussed.

\section{Experimental details}

\section{Apparatus and reagents}

The setup consisted of an usual piezoelectric quartz crystal AT-cut, with gold electrodes of active superficial area about 0.40 $\mathrm{cm}^{2}$, operating at a fundamental frequency of 10 $\mathrm{MHz}$ (ICM, Oklahoma, OK, USA). This sensor was housed in the glass detector cell developed for optimum exposure of the gas stream to the crystal, as described before [19]. Each crystal was powered by a homemade oscillator operating in parallel resonance. The monitoring of each output frequency was carried out by using a Sincler frequency counter. The output frequency was recorded every 30 and $60 \mathrm{~s}$ at a $0.1 \mathrm{~Hz}$ resolution (gate time $=1 \mathrm{~s}$ ). The working temperature was fixed at $25.0 \pm 0.1{ }^{\circ} \mathrm{C}$ for all measurements (except for the study of the temperature effect).

Calibrated flowmeters (Matheson and Cole-Parmer) were used to monitor the flow rates of the carrier $\left(\mathrm{N}_{2}\right.$ or dried air) and sample gas $(\mathrm{CO})$ streams. Pressurized cylinders from Aga Company were employed as reliable sources, carbon monoxide $10 \%$ (v/v) being already diluted with pure nitrogen. Analytical grade reagents were used for the preparation of all substances tested as coatings.

\section{Coating preparation}

The best coating material found for the $\mathrm{CO}$ gas was a $50 \%(\mathrm{v} / \mathrm{v})$ mixture of saturated nickel(II)-phthalocyanine (in ethanol) and glycerol-99 \% pure. Other different ratios were 
tested with little success, and criteria used for choosing the best component ratio was the maximum sensitivity reached. The crystals were coated with these substances by direct application of a small amount of the adsorbent material over the surfaces of the electrode (both gold faces of a thin piezoelectric crystal), using a microsyringe, and the viscous solution was spread with a tiny glass rod. All the material stays just on the gold electrode area leaving a reproducible film, which can have its mass (ca. 70-75 $\mu \mathrm{g}$ ) controlled by monitoring the frequency change of the crystal and calculated from the Sauerbrey equation [1].

\section{Vapour mixing}

The various concentrations of carbon monoxide were prepared by using the flow dilution method in nitrogen. Samples from the generation system were introduced into the detector cell by a four-port sampling valve (Varian). In operation, the carrier gas was first allowed to pass through the crystal sensor until the baseline frequency became stable. The sampling valve was then rotated to introduce the sample into the detector cell, where the interaction between the sample gas and the coating took place. After equilibrium was reached, the frequency reading became stable. The response was taken as the difference between the frequency of baseline before sampling and the frequency obtained after the established exposure time. When the sample valve was rotated again, allowing nitrogen to pass through the cell, desorption occurred and the frequency returned to the original baseline, being the detector ready to be used again.

\section{Results and Discussion}

\section{Development and amount of coating material}

The selection of a compound (or mixture) to be used as a piezoelectric quartz crystal coating is of utmost importance in the development of a chemical sensor. Recently, the relevant parameters to be evaluated (stability, sensitivity, reversibility, response time, reproducibility, and selectivity), and the main variables affecting the results and influencing the choice of coating were discussed and illustrated with experiments performed during the evaluation of coatings for carbon dioxide detectors [20].

The choice of NiPc was based on spectroscopic studies of Pc materials in the visible and infrared spectral regions, and their gaseous adsorption-desorption properties were studied using Langmuir-Blodgett (LB) films [21]. It was also found that the central metal atom played a key role in the gas-film interaction mechanism [22]. Because the electronic spectrum (ES) is one of the probes used to monitor such interactions, the characteristics and changes in these spectra $(\mathrm{Pc}$ complexes) imposed by the central metal atom are of current interest.

When the mixture NiPc/Glycerol was used as coating, the signal magnitude $(\Delta \mathrm{F})$ increased with a increasing of substrate amount until it reached a frequency shift of about $30 \mathrm{KHz}$. After this point, the response did not increase any more (stability). Too much material usually lead to total cessation of the crystal oscillations. Consequently, the optimal amount of mass (coating) was considered to be $70-75 \mu \mathrm{g}$ (30 KHz, under our experimental conditions).

\section{Effect of the flow rate on the response and reversibility}

In general, the piezoelectric-detector response is also very much influenced by the flow rate of the carrier gas in a flow analysis. For the selected coating material, an increase in the flow rate leads to a larger signal as far as approximately $72 \mathrm{~mL} \mathrm{~min}^{-1}$. After this value, a reduction in the signal magnitude (Fig. 1) occurs, but the desorption time is also shortened. However, the use of a faster carrier gas flow rate also results in some disadvantageous effects such as accelerated damage by physical forces or even by volatilization (loss) of the coating material, which hinders return to the baseline frequency. Thus, an appropriate choice of the working flow rate when using this species as detector should be the main concern among all the above factors mentioned. For the studied coating material, a flow rate of approximately $72 \mathrm{~mL} \mathrm{~min}^{-1}$ was considered to be ideal and complete gas desorption (reversibility, recovery, or regeneration time) took about two minutes. 


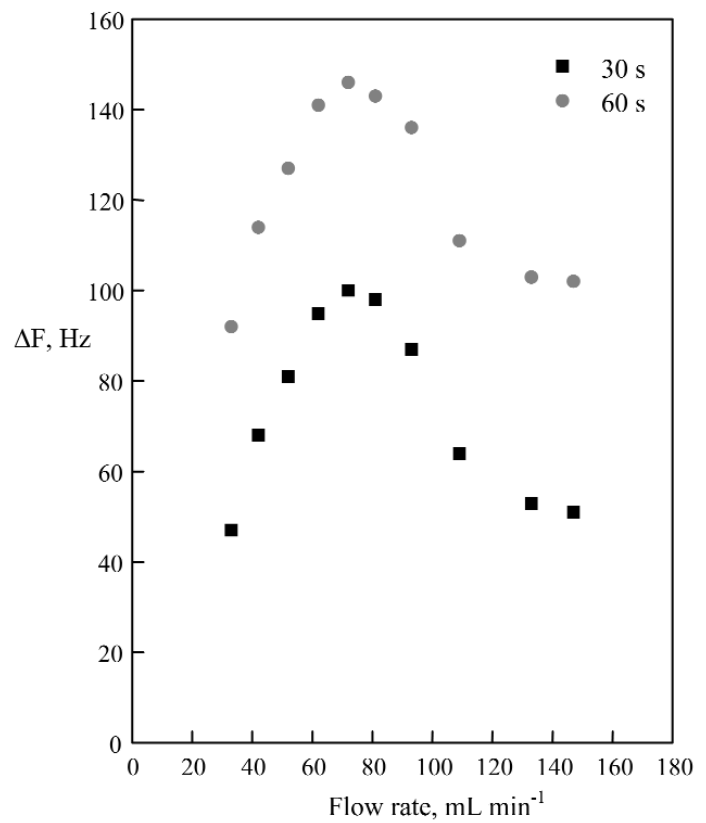

Figure 1. Effect of flow rate on the response of the NiPc/glycerine coating: $\mathrm{C}_{\mathrm{CO}}=1.1 \%(\mathrm{v} / \mathrm{v})$, temperature $25^{\circ} \mathrm{C}$, amount of coating $=76 \mu \mathrm{g}$, and different sampling times.

\section{Effect of room temperature}

Some captor films or substrates are very sensitive to temperature changes[23], so rigid control is necessary in practical experiments. Various factors such as sorption sensitivity and desorption rate may depend on the selected operational temperature.

In this study, the carrier gas (nitrogen) was passed through a coil placed in a controlled thermostated bath. The response of the $\mathrm{CO}$ sensor was studied in the temperature range of $20-70^{\circ} \mathrm{C}$. Results indicated that an increase in temperature led to an increase in sensitivity of about $2 \mathrm{~Hz} /{ }^{\circ} \mathrm{C}$ (Fig.2). Therefore, a more complete study on the stability of the coating material at higher working temperatures should be carried out, in the near future, in an attempt to obtain even more better results (sensitivities).

Calibration curves, precision, stability and interferents

Typical response analytical curves, $(\Delta \mathrm{F}, \mathrm{Hz})$

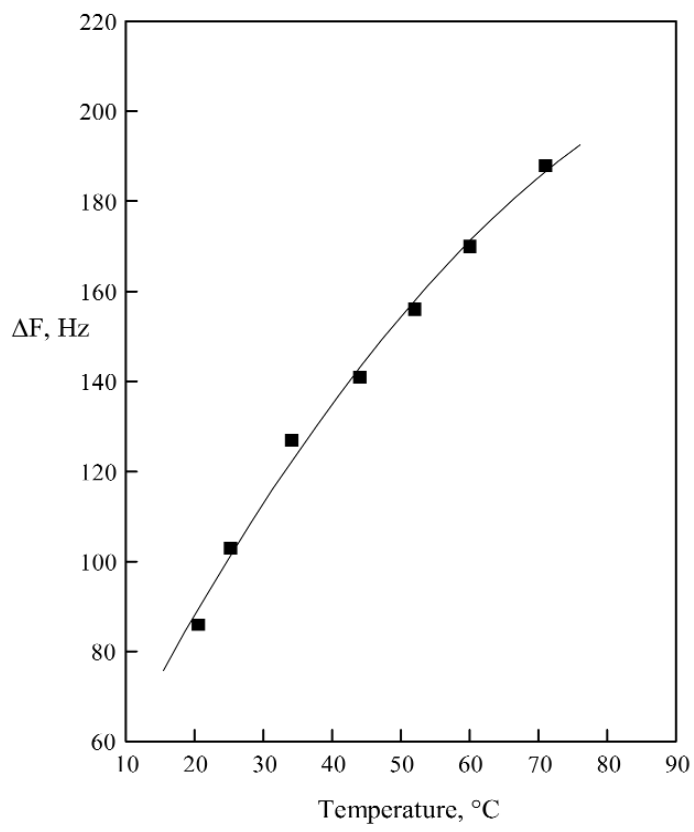

Figure 2. Effect of temperature on the response of the sensor: $\mathrm{C}_{\mathrm{CO}}=1.07 \%(\mathrm{v} / \mathrm{v})$, flow rate $=62 \mathrm{~mL}$ $\mathrm{min}^{-1}$, amount of coating $=75 \mu \mathrm{g}$, and sampling time $30 \mathrm{~s}$.

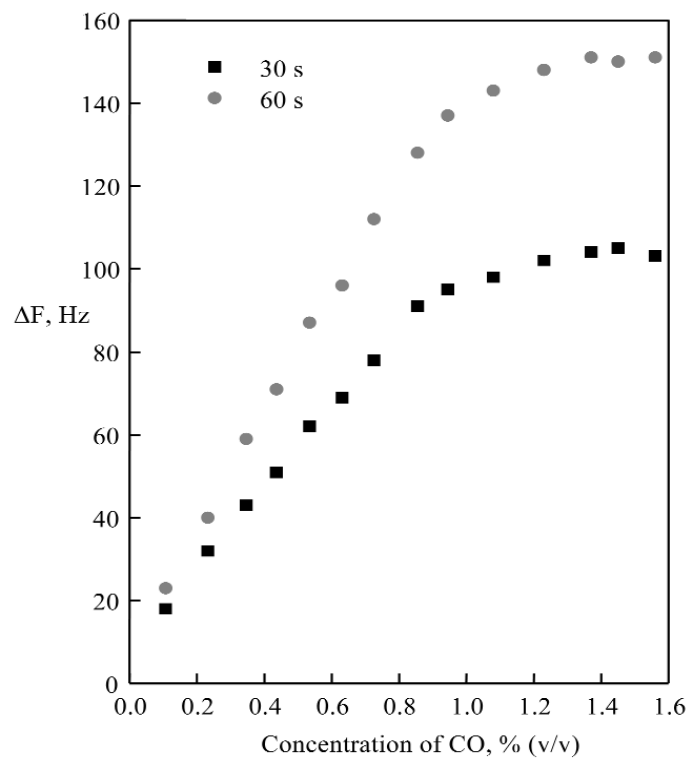

Figure 3. Response of the NiPc/glycerine coating to different $\mathrm{CO}$ concentrations and exposure times: working temperature $=25^{\circ} \mathrm{C}$, amount of coating $=76 \mu \mathrm{g}$, flow rate $=62 \mathrm{~mL} \mathrm{~min}^{-1}$, and sampling times $=30$ and $60 \mathrm{~s}$. 
vs. CO concentration, are shown in Fig.3 for two different contact times. It was found that this dependence is linear in the studied concentration range from 0.10 to $1.0 \% \mathrm{v} / \mathrm{v}$. Good linearities ( $\mathrm{r}=$ 0.9982 and 0.9988 ) were obtained with sensitivities of 8.94 and $9.54 \mathrm{~Hz} / \mathrm{ppM}$, for exposure times between the pollutant and the sensor of 30 and 60 seconds, respectively. Although the sensitivity encountered at room temperature is not high enough to allow general determinations, this method can be applied in some special situations [24-26].

Table 1 shows the results of the precision studies for 10 different crystals, where standard deviations of about 3.3 and $5.4 \mathrm{~Hz}$ were obtained for sampling times of 30 and 60 seconds, respectively.

Table 1. Precision measurements on the responses of the $\mathrm{CO}$ sensor: amount of coating $=76 \mu \mathrm{g}$, flow rate $=62 \mathrm{~mL} \mathrm{~min}^{-1}$, and $\mathrm{C}_{\mathrm{CO}}=1.07 \%(\mathrm{v} / \mathrm{v})$

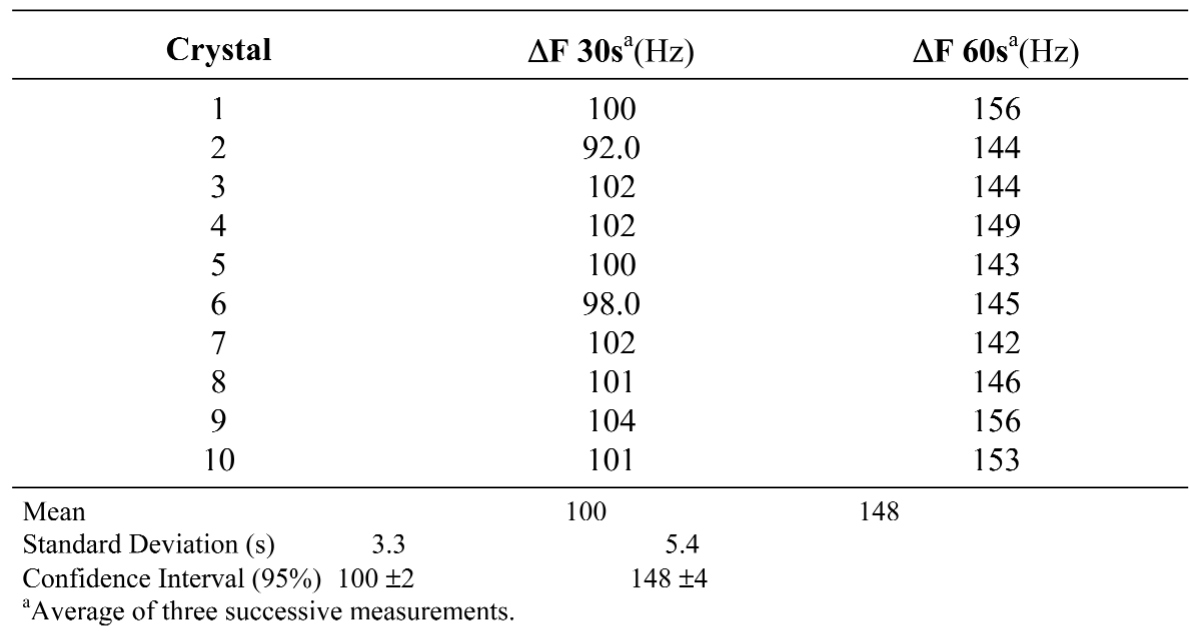

Table 2. Lifetime measurements on the responses of the $\mathrm{CO}$ sensor: amount of coating $=76 \mu \mathrm{g}$, flow rate $=62 \mathrm{~mL} \mathrm{~min}^{-1}$, and $\mathrm{C}_{\mathrm{CO}}=1.07 \%(\mathrm{v} / \mathrm{v})$ and temperature $=25^{\circ} \mathrm{C}$

\begin{tabular}{ccc}
\hline Time & $\Delta \mathbf{F} \mathbf{3 0 s}^{\mathrm{a}}(\mathrm{Hz})$ & $\Delta \mathbf{F ~} \mathbf{6 0 s}^{\mathrm{a}}(\mathrm{Hz})$ \\
\hline 0 & 102 & 156 \\
$15 \mathrm{~min}$ & 103 & 156 \\
$30 \mathrm{~min}$ & 101 & 154 \\
$1 \mathrm{~h}$ & 102 & 153 \\
$2 \mathrm{~h}$ & 101 & 152 \\
$4 \mathrm{~h}$ & 100 & 152 \\
$6 \mathrm{~h}$ & 101 & 153 \\
$12 \mathrm{~h}$ & 102 & 150 \\
$24 \mathrm{~h}$ & 102 & 150 \\
$48 \mathrm{~h}$ & 101 & 151 \\
$72 \mathrm{~h}$ & 98 & 148 \\
7 days & 98 & 145 \\
10 days & 97 & 144 \\
15 days & 95 & 144 \\
\hline
\end{tabular}

${ }^{a}$ Average of three successive measurements. 
Table 3. Effect of some substances as possible interferents on $\mathrm{CO}$ determination: $\mathrm{C}_{\text {interferent }}=$ $10 \% \mathrm{v} / \mathrm{v}$ (except other notation), amount of coating $=70 \mu \mathrm{g}$, flow rate $=80 \mathrm{~mL} \mathrm{~min}^{-1}$, and temperature $=25^{\circ} \mathrm{C}$

\begin{tabular}{|c|c|}
\hline Tested substances & 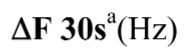 \\
\hline Dry air & 9 \\
\hline $\mathrm{CO}_{2}$ & 26 \\
\hline $\mathrm{SO}_{2}$ & 47 \\
\hline $\mathrm{NO}_{2}$ & 426 \\
\hline $\mathrm{H}_{2} \mathrm{~S}$ & 246 \\
\hline $\mathrm{H}_{2} \mathrm{O}(60 \% \mathrm{v} / \mathrm{v})$ & no vibration \\
\hline $\mathrm{HCl}$ & 78 \\
\hline $\mathrm{NH}_{3}$ & 15 \\
\hline $\mathrm{CO}(1 \% \mathrm{v} / \mathrm{v})$ & 100 \\
\hline
\end{tabular}

${ }^{\text {a }}$ Average of three measurements.

The lifetime of a single coating (crystal) was observed for fifteen days (Table 2), and the results show good stability (loss of 7\%). Measurements carried out for a contact time of 30 seconds were also more reproducible in this study. When not in use, the crystal was stored in a desiccator (under vacuum).

Interference of some species such as carbon dioxide, sulfur dioxide, nitrogen dioxide, hydrogen sulfide, hydrogen chloride, ammonia, dry air, and water vapour, which are expected to exist in the air environment and maybe a potential interferents, were tested at $10 \%(\mathrm{v} / \mathrm{v})$ concentration level except for moisture. The syringe dilution method was used to obtain this value for all these substances. In these conditions, the present study has shown that only $\mathrm{NO}_{2}, \mathrm{H}_{2} \mathrm{~S}$, and moisture cause significant frequency changes in comparison with that observed for $1 \%(\mathrm{v} / \mathrm{v})$ carbon monoxide (Table 3).

\section{Conclusions}

The nickel(II)-phthalocyanine/glycerol mixture tested as substrate in this work is potentially good for use as gas captor on the piezoelectric sensor, being suitable for carbon monoxide determination in the concentration range 0.10 to $1.0 \%(\mathrm{v} / \mathrm{v})$. Although the sensitivity encountered at room temperature is not high enough to allow general determinations, this method can be applied in some special situations. A sample of the exhaust gas from a car could be collected into a sampling bag and analyzed in the laboratory without $\mathrm{CO}_{2}$ interference, using absorbent tubes (soda lime) placed before the crystal cell, in the line. The concentration range of interest for carbon monoxide depends on the sample, and although in the environment the "safe" concentration limit is placed at 1000 ppm (1 $\mathrm{ppM})$, the concentration in cigarette smoke reaches $40 \mathrm{ppM}(4.0 \%)$, which is in the useful range. Carbon monoxide analysis in unpolluted areas, $0.1-0.2 \mathrm{ppm}$, can only be achieved with some previous preconcentration treatment. The amount of $\mathrm{CO}$ in gaseous fuels is much higher and depends on its origin. It ranges from a few percent 4-18\% (v/v) in coal gas, $27 \%$ in blast furnace gas, and around $29 \%$ in producer gas, to $30-41 \%$ in water gas. So, $\mathrm{CO}$ concentration in gaseous fuels could be determined by the present method.

It was observed that the interaction between $\mathrm{CO}$ and $\mathrm{NiPc}$ increases at higher temperatures. So, in future studies, new efforts in this direction will be important if higher sensitivities are to be achieved.

Another way to try to improve the sensitivity of the sensor would be to test different methods for the film preparation (coatings). Electrochemical depositions, deposition by vacuum sublimation, or the use of Langmuir- 
Blodgett films furnish more compact and homogeneous coatings, allowing still more effective control on their thickness. Another advantage of chemical immobilization (LangmuirBlodgett films) is the possible shorter response time due to the lower influence of diffusion phenomena on the film surface.

\section{Acknowledgments}

The authors are grateful to the CNPq, FAPESP and CAPES for financial support.

Recebido em: 13/09/2006

Aceito em: 07/11/2006

O. M. Guimarães, M. E. D. Zaniquelli,J. R.M. Castro, V. R. Balbo e J. F. Andrade. Determinação de monóxido de carbono usando um sensor de cristal de quartzo revestido.

Resumo: Monóxido de carbono foi detectado e determinado por meio de um sensor piezelétrico de cristal de quartzo, cujos eletrodos foram revestidos com um filme formado por uma solução saturada de níquel(II)-ftalocianina (em etanol) e glicerina pura, na proporção $50 \%$ (v/v). Realizaram-se estudos sobre o efeito da temperatura, vazão e a presença de algumas outras substâncias (possíveis interferentes). Elaboração de curvas de calibração, estabilidade do sensor (tempo de vida) e estudos de repetibilidade também foram verificados. A seletividade resultante é provavelmente devida à ligação coordenativa entre os complexos eletronicamente insaturados do metal e o analito. A curva analítica é linear no intervalo de concentração entre 0,10 e $1,0 \%(\mathrm{v} / \mathrm{v})$.

Palavras-chave: monóxido de carbono; sensor piezelétrico; níquel(II)-ftalocianina; cristal de quartzo.

\section{References}

[1] G. Sauerbrey, Z. Phys. 155 (1959) 206-22.

[2] K. Bodenhöfer, A. Hierlemann, G.Noetzel, U. Weimar and W. Göpel, Anal. Chem. 68 (1996) 2210-18.

[3]W.P. Carey, K.R. Beebe and B.R. Kowalski, Anal. Chem. 58 (1986) 149-53.

[4] D.S.Ballantine, S.L. Rose, J.W. Grate and H. Wohltjen, Anal. Chem. 58 (1986) 3058-66.

[5] M.S. Nieuwenhuizen and A.W. Barendsz, Sens. Actuators 11 (1987) 45-62.

[6] D.M. Oglesby, B.T. Upchurch, B.T. Leighty, J.P. Collman, X. Zhang and P.C. Herrmann, Anal. Chem. 66 (1994) 2745-51.

[7] J.F. Alder and J.J. McCallum, Analyst 108 (1983) 1169-89.

[8] M.S. Nieuwenhuizen and J.L.N. Harteveld, Talanta 41 (1994) 461-72.

[9] J.J. McCallum, P.R. Fielden, M. Volkan and J.F.Alder, Anal. Chim. Acta 162 (1984) 75-83.

[10] G-Z. Zhang and E.T. Zellers, Anal. Chem. 65 (1993) 1340-49.

[11] E.T. Zellers, R.M. White and S.M. Rappaport, Anal. Chem. 62 (1990) 1222-27.

[12] E.T. Zellers, N.Hassold, R.M. White and S.M. Rappaport, Anal. Chem. 62 (1990) 1227-32.

[13] E.T. Zellers and G-Z. Zhang, Anal. Chem. 64 (1992) $1277-84$

[14] E.T. Zellers and G-Z. Zhang, Anal. Chim. Acta 280
(1993) 1-13.

[15] V. Schurig and W.J. Burkle, J. Am. Chem. Soc. 104 (1982) 7573-80.

[16] A. Hierlemann, K. Bodenhöfer, M. Fluck, V. Schurig and W.Göpel, Anal. Chim. Acta 346 (1997) 327-39.

[17] R. Zhou; F. Josse; W. Göpel; Z.Z. Öztürk and Ö. Bekaroglus, Appl. Organomettalic. Chem. 10 (1996) 557-77.

[18] O.M. Guimarães, J.F. Andrade and D.P.Ruys, Anal. Lett. 30 (1997) 2159-74.

[19] D.P. Ruys, J.F. Andrade and O.M.Guimarães, Anal. Chim. Acta 404 (2000) 95-100.

[20] M.T.S.R. Gomes, A.C. Duarte and J.A.B.P. Oliveira, Talanta 48 (1999) 81-9.

[21] D. Battisti and R. Aroca, J. Am. Chem Soc. 114 (1992) 1201-04.

[22] R. Rousseau, A. Ozarowski, R. Aroca, L.A. Soares II and M. Trsic, J. Mol. Struct. 317 (1994) 287-97.

[23] M.S. Nieuwenhuizen and A.J. Nederlof, Anal. Chem. 60 (1988) 236-40.

[24] B.M. McCormac, Introduction to the Scientific Study of Atmospheric Pollution, D. Reidel Publishing Company, Dordrech, 1971, pp.34-40.

[25] M.T.S.R. Gomes; P.S.T. Nogueira, A.C. Duarte and J.A.B.P. Oliveira, Analyst, 124 (1999) 1449-53.

[26] H.M. Spiers, Technical Data on Fuel, The British National Committee World Power Conference, London, 1962, p.255. Apud ref. 25. 